UDC $628.16 .08+628.16 .067 .1$

Petro G. Kyriienko, $\mathrm{PhD}$, docent of Department of chemistry, ecology and expert technologies

ORCID ID: 0000-0002-8116-7448 e-mail: p.kirienko@khai.edu

Valentyna V. Kyriienko, student

Andriy V. Chumachenko, Senior Lecturer

National Aerospace University “Kharkiv Aviation Institute”, Kharkiv, Ukraine

\title{
PORTABLE DEVICE FOR WATER PURIFICATION
}

\begin{abstract}
The two-stage system of surface water purification in field conditions in a portable device for water purification is considered. In the first stage, water is filtered through a hair pad, and on the second it is filtered through zeolite, shungite or track membrane and disinfected internally. In a portable device, water can be cleansed from heavy metals, chemicals, pesticides, phenols, organic contaminants, nitrates, petroleum products, ammonia, viruses, pathogenic microorganisms. Portable water purification device can be used in the field by tourists, travellers, military personnel.
\end{abstract}

Key words: portable device for water purification; shungite; zeolite; track membranes; anthropogenic pollution of water; disinfection of water; mechanical filter

\section{Introduction}

Water resources of Ukraine consist of surface river runoff and fresh groundwater. Salty seawater has constraints in water supply. The superficial part of the river runoff is very variable and has been regulated for use in water supply.

There are three types of rivers. The first type includes plain ones, characterized by wide valleys with gentle banks. The velocity of the flow is $0.2 \ldots 0.5 \mathrm{~m} / \mathrm{sec}$ as the minimum, and due to flood is increased to $1 \mathrm{~m} / \mathrm{sec}$. In the summer part of this rivers dry up. The second type includes the Polissya rivers. They are characterized by swampy river basins. The third type combines mountain rivers. These are the rivers of the Carpathians and the Crimea. They are characterized by steep slopes, not wide and deep valleys. The speed of this rivers reaches $1 \ldots 2 \mathrm{~m} / \mathrm{sec}$ at low, and $3 \ldots 5 \mathrm{~m} / \mathrm{sec}$ in flood.

In addition, in Ukraine there are more than 7 thousand lakes, 23 thousand artificial ponds and reservoirs.

For drinking water supplying, underground water is preferred, especially that is inter-bilayer pressure water.

Natural water is a multicomponent heterogeneous system that contains various impurities, both in dissolved and in an insoluble state. The purity of natural waters is characterized by physical, chemical, bacteriological and biological indicators. Physical indicators include, first of all, organoleptic parameters (odour, taste, transparency, turbidity, appearance, suspended matter). Chemical indices are characterized by an active reaction of $\mathrm{pH}$, hardness, concentration of nitrogencontaining substances, sulfates, sulfides, phosphates, manganes, some poisonous

(c) P.G. Kyriienko, V.V. Kyriienko, A.V. Chumachenko, 2019 
substances, radionuclides, and others. Bacteriological parameters are characterized by the presence of coliform and other pathogenic bacteria in water. Biological indicators are determined by aquatic organisms of the reservoir and vegetation.

Anthropogenic pollution of natural reservoirs occurs as a result of human economic activity. The ecological condition of many reservoirs is unsatisfactory. Drinking water from them without the necessary technological treatment is impossible. To ensure drinking water consumption in the field, it is necessary to have portable equipment for water purification from harmful to human health chemical compounds, from pathogenic bacteria, and disinfection of surface water.

Today, for travellers, tourists, hunters, fishermen, the militaries there are many handheld devices for water purification. They can be individual and group; using electricity and autonomous; with chemical, complete purification and with purification followed by boiling (disinfection); one-time and multiple.

The groups are usually used for expeditions. Such devices use traditional water purification and disinfection systems, requiring pumping equipment and the availability of electricity. Devices with incomplete cleaning (without decontamination) can use surface water without chemical contamination (this must first be known), followed by boiling, or thermal decontamination.

Reusable and disposable portable devices of individual using differs in cost characteristics, as well as water filtration systems used for water purification.

Individual devices for water purification are made by many firms. Reviews from consumers are ambiguous: from outright denial of use to use with next boiling of purified water. The cost of portable devices ranges from 600 to $1000 \mathrm{hrn}$., and foreign ones - from $\$ 250$ to 380 .

Among the filters that are used in portable devices, membrane systems are most commonly used. Not all membrane systems can be used in portable devices. Membranes can be classified according to the following features:

- by the nature of the material from which the membranes are made: polymeric, non-polymeric. Polymeric membranes, depending on the type and the chemical composition of the polymer, can be cellulose, acetylcellulose, polyamide, and others. Inorganic - metal, ceramic, graphite, glass, zeolite, offset, shungite;

- the geometric shape of the membranes can be in the form of films, plates, tubes, hollow fibers. The thickness of the films can be 100-150 microns, the plates 2 ... $3 \mathrm{~mm}$;

- on functional features: dialysis, electrodialysis (ion exchange), microfiltration, ultrafiltration, nano-filtration;

- for the porous structure of the membrane they may be: non-porous (diffusion), porous, composite;

- by the method of obtaining membranes can be: dry, wet (swollen in a solvent), polymeric, track, liquid, dynamic (deposited by spraying, sintering), and others.

\section{The authors offer}

Taking into account weight, geometric, functional and other characteristics of filter materials for individual portable water purification devices, the following materials can be distinguished: zeolite, opretite, shungite as natural sieve; tracks and composite films as microfiltration, ultrafiltration, nano-filtration materials. All listed characteristics (weight, geometric, functional) are present in the resulted materials. 
Among other characteristics of filter materials, it is necessary to take into account the chemical characteristics for the removal of chemical compounds of sulfates, sulfides, phosphates, poisonous substances, radionuclides from water, as well as the removal of pathogenic bacteria, colic forms from the water.

Due to the fact that the portable device for water purification should be carried, its weight should be minimal, in volume of $1 \ldots 1,5$ litres. It should clean water from surface sources from all available contaminants, and disinfect purified water in the device itself.

Let's consider several possible options.

Water purification using track membranes. The industry produces track membranes made of polyethylene terephthalate film with the following characteristics:

- the diameter of the holes (pores) can be from 0.05 to 5 microns, with a density of $10^{5}-3 \cdot 10^{9}$ pores $/ \mathrm{cm}^{2}$;

- the same pore diameter with a deviation of no more than 5\%;

- operating temperature range up to $120^{\circ} \mathrm{C}$;

- passive in the biological sense;

- filtration through the membrane can occur with an overpressure of $0.01 \mathrm{MPa}$;

- can be used for the microfiltration process;

- in drinking water significantly reduces the concentration of pathogenic bacteria, harmful chemical impurities, heavy metals, radionuclides, pesticides.

Use as a filtering material shungite - a natural composite with the general formula $\mathrm{C}_{79} \mathrm{H}_{19} \mathrm{O}_{1,5} \mathrm{~N}_{0,3}$. It consists of carbon by $92-98 \%$ and belongs to anthraxolites. Shungite is a unique adsorbent, has high catalytic activity, bactericidal properties. The structure of shungite includes fullerenes - allotropic varieties of carbon with a unique structure. This will allow to remove humic substances and salts of heavy metals from the water. Due to bactericidal and sorption properties, shungite can purify water from spores of plants, viruses, biological toxins, helminthic eggs. As a result of interaction with water shungit gives it transparency, neutralizes a specific smell and an unpleasant smack. The natural filter of shungite promotes saturation of water with useful macro- and microelements in the most optimal concentration for human organism.

Zeolite, Aluminium and alkaline earth metal alumina silicate, sorbent of volcanicsedimentary origin, clinoptilolite type. The chemical formula $(\mathrm{NaK})_{6}\left[\mathrm{Al}_{6} \mathrm{Si}_{30} \mathrm{O}_{72}\right] \cdot 24 \mathrm{H}_{2} \mathrm{O}$ with a diameter of the inlet holes from 0.3 to $1 \mathrm{~nm}$. Zeolite works as a sieve. It absorbs or passes those molecules whose dimensions are less than porous in the zeolite itself. Everything else is delayed on its surface. It can clean water from harmful substances such as heavy metals, chemicals, pesticides, radioactive elements, phenols, organic pollutants, ammonia, nitrates, bacteria, petroleum products, viruses, pathogenic microorganisms, ammonia.

For cleaning water in a portable device, a two-stage cleaning system is used. At the first stage, mechanical cleaning is used. Water is filtered through a mechanical filter. At this stage, all mechanical impurities and voids are removed from the water; partially water is lightened, it is deprived of colour. The mechanical filter consists of a hair pad, which is located in an inlet pipe. It can be removed, washed out, or simply changed. The duration of the mechanical filter depends on the pollution of the source water, but not less than $10 \ldots 15$ cycles. 


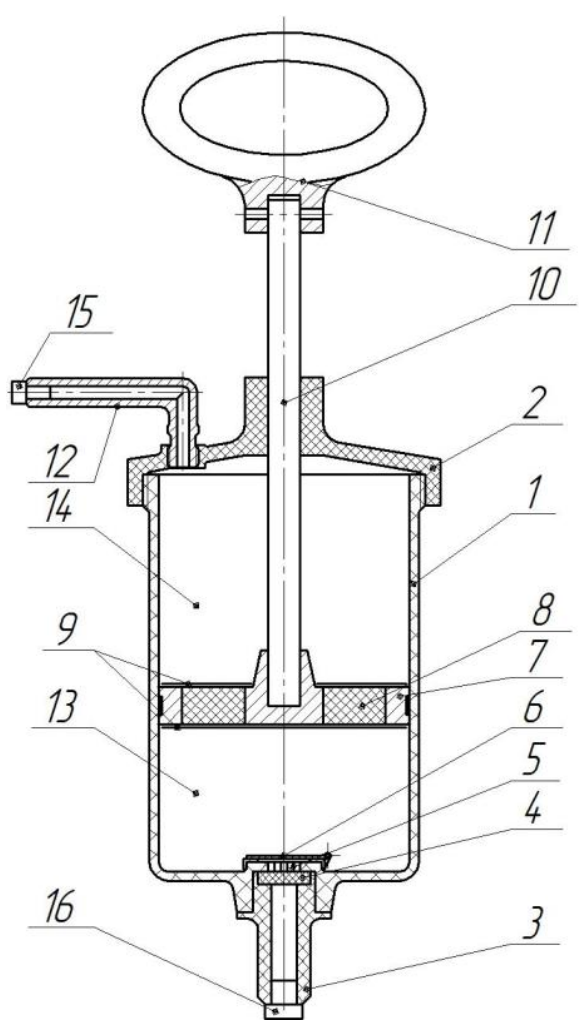

Fig. 1 - A portable device for water purification:

1 - body; 2 - cover; 3 - inlet pipe; mechanical filter; 5 - holes; 6 - return valve; 7 - piston; 8 - filter; 9 - silver plated net; 10 - stock; 11 - a handle; 12 - fitting; 13 - cavity in front of the piston; 14 - cavity above the piston; 15,16 - stubs

Then the water is sucked into the vessel by a piston system. On the piston can be placed zeolite, shungite or track filters, as well as silver plated net for additional disinfection of water. Treatment of water, which contains $0.05 \ldots 0.2 \mathrm{mg} / \mathrm{dm}^{3}$ of silver within $30 \ldots 60$ minutes, allows to achieve sanitary norms [2]. This is the second stage of cleaning and disinfecting water.

In Fig. 1 schematically depicts a portable device for water purification.

The device works as follows. The water through the mouthpiece 3 is suctioned through the mechanical filter 4 , the holes in the body 5 , the return valve 6 in the prefilter cavity 13 by the piston 7 . In this case, the water is purged by passing through the mechanical filter 4 from the mechanical impurities, and the return valve 6 in this time remains open. When the piston 7 moves in the opposite direction, the return valve 6 is closed and the water is filtered through the filter 8 into the cavity 14 . The water contacts the silvered net 9 and is disinfected, and filtering through the filter 8 , which can be made of shungite, opretite or track membrane, is finally cleared from the pollutants mentioned above. The purified water collected in the cavity 14 through the pipe connector 12 during the opposite movement of the piston 7 is delivered to consumer, while the next portion of the water can be sucked into the cavity 13 for purification. The cleaned water in the cavity 14 and the water collected for cleaning in the cavity 13 is not mixed because the water filtering through the filter 8 needs to create overpressure. 
The water collected in the portable device with closed plugs 15 and 16 can be saved already purified. To minimize the weight of the portable device, it must be made of food plastic, and to minimize the size, it is necessary that the handle must be folding.

\section{Conclusions}

The article analyses materials from which it is necessary to make filters for portable devices, so that purified water meets sanitary norms.

The proposed portable device combines the processes of cleaning and disinfecting water, does not use chemical reagents, is self-cleaned and completely autonomous.

The proposed construction of a portable device for water purification is confirmed by a patent [1].

\section{REFERENCES}

1. Патент 114353 UA, MПK B01D 35/26 (2006.01) B01D 24/10 (2006.01) C02F 3/06 (2006.01) Переносний пристрій для очищення води / Кирієнко А.П., Кирієнко П.Г., Сідаченко О.А., Ковнацький О.С.; заявл. 14.07.2015; опубл. 25.05.2017, Бюл.№10, 2017 р. 2. Запольський А.К. Водопостачання, водовідведення та якість води: Підручник. - К.: Вища школа, 2005. - $671 \mathrm{c.}$

3. Брек, Д. Цеолитовые молекулярные сита [Текст]: пер. с англ. / Д. Брек. - М.: "Мир", 1976.

4. Мала гірнича енциклопедія : у 3 т. / за ред. В. С. Білецького. Т. 3 : С - Я / [Альохін В.І. та ін.]. - Донецьк : Сх. вид. дім, 2013. - 642.

\section{REFERENCES (TRANSLATED AND TRANSLITERATED)}

1. Kyrijenko, A., Kyrijenko, P., Sidachenko, O., \& Kovnac'kyj, O. (2017). UA. Patent No. 114353 MПK B01D 35/26 (2006.01) B01D 24/10 (2006.01) C02F 3/06 (2006.01) Perenosnyj prystrij dlja ochyshhennja vody. UA (in Ukrainian).

2. Zapol's'kyj, A. K. (2005). Vodopostachannja, vodovidvedennja ta jakist' vody. Kyiv: Vyshha shkola (in Ukrainian).

3. Brek, D. (1976). Ceolitovye molekuljarnye sita. Moscow: Mir (in Russian).

4. Al'ohin, V. I. (2013). Mala girnicha enciklopedija. Vol. 3 S-Ya (3 vols.) (V. S. Bilec'kij, Ed.). Donec'k: Sh. vid. dim. (in Ukrainian).

The article was received 14.12.2018 and was accepted after revision 28.12.2018

\section{П.Г. Кирієнко, В.В. Киріснко, А.В. Чумаченко \\ ПЕРЕНОСНИЙ ПРИСТРІЙ ДЛЯ ОЧИЩЕННЯ ВОДИ}

Анотація. Розглянуто двоступеневу систему очищення поверхневих вод в польових умовах в переносному пристрої для очищення води. На першому етапі вода фільтрується через волосяну набивку, а на другому фільтрується через цеоліт, шунгіт або трекову мембрану та обеззаражується в самому пристрої. У переносному пристрої вода може очищуватись від важких металів, хімікатів, пестицидів, фенолів, органічних забрудників, нітратів, нафтопродуктів, аміаку, вірусів, патогенних мікроорганізмів. Переносний пристрій для очищення води може використовуватись в польових умовах туристами, мандрівниками, військовими.

Ключові слова: переносний пристрій для очищення води; шунгіт; цеоліт; трекові мембрани; антропогенне забруднення води; обеззараження води; механічний фільтр 


\section{Киріснко Петро Григорович}

кандидат технічних наук, доцент, доцент кафедри хімії, екології та експертизних технологій Національного аерокосмічного університету ім. М.С. Жуковського "Харківський авіаційний інститут"

Адреса робоча: 61070 Україна, м. Харків, вул. Чкалова, 17

тел.+380506194055 e-mail: p.kirienko@khai.edu

ORCID ID: 0000-0002-8116-7448

\section{Киріснко Валентина Володимирівна}

студентка Національного аерокосмічного університету ім. М.Є. Жуковського «Харківський авіаційний інститут»

Адреса робоча: 61070 Україна, м. Харків, вул. Чкалова, 17

\section{Чумаченко Андрій Вікторович}

старший викладач кафедри графіки та комп'ютерного моделювання Національного аерокосмічного університету ім. М.С. Жуковського «Харківський авіаційний інститут»

Адреса робоча: 61070 Україна, м. Харків, вул. Чкалова, 17 тел. 0573150556 